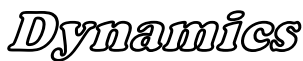

\section{Contingency and its consequences in Tristram Shandy by Laurence Sterne}

\author{
Tomasz Umerle \\ umerle1@poczta.onet.pl
}

\begin{abstract}
:
My paper proposes a new approach to the famous novel by Laurence Sterne Tristram Shandy. In my reading of this work I use the category of contingency which I define by referring to the German philosopher Odo Marquard and literary theories of a monographer of the contigency in literature and film Rafał Koschany. These are the basic inspirations for reflections on Tristram as a character, and simultaneously, narrator in the novel.

In my view contingency manifests itself in Sterne's work in a two-fold manner it affects Tristram's life and narration. I will try to focus on the different ways in which these manifestations relate to each other.
\end{abstract}

Key words: Sterne, Tristram Shandy, contingency, novel, narration.

The subject of this study will be the category of contingency in the case of The Life and Opinions of Tristram Shandy, a well-known novel by the $18^{\text {th }}$-century writer L. Sterne. This category of contingency will reveal new interpretative insights in the ongoing discussion of this still-intriguing work.

Contingency manifests itself in Tristram in a two-fold manner. This division is strictly contractual because these "modes of functioning" of contingency in the novel are in a dynamic relation with each other. At the chronological beginning of the plot contingency appears as a plot-related fact. Mr. and Mrs. Shandy used to fulfill their marital duty in a routine way, that is, once a month, when Walter Shandy (Tristram's father) set the watch. One day a disturbance in this order appeared when Tristram's mother asked her husband to check the mechanism. As Walter says: "it was a very unseasonable question at least, - because it 
scattered and dispersed the animal spirits, whose business it was to have escorted and gone hand-in-hand with the HOMUNCULUS, and conducted him safe to the place destined for his reception" (Sterne 2003, p. 6).

Tristram shares Walter's negative opinion about this event: "I wish either my father or my mother (...) had minded what they were about when they begot me; had they duly consider'd how much depended upon what they were then doing; - that not only the production a rational Being was concern'd in it, but that possibly the happy formation and temperature of his body, perhaps his genius and the very cast of his mind; - and, for aught they knew to the contrary, even the fortunes of his whole house might take their turn from the humours and dispositions which were then uppermost" (Sterne 2003, p. 5).

It is worth noting that in other places in the novel, the hero-narrator tends to treat his father's views as ironic, but here he adopts them to a significant degree. This "adoption" is not meaningless. It is maintained, despite partial compensation, throughout the whole story as Tristram's interpretation of his own existential experience, and Walter himself will address this topic near the end of the novel.

The description of this event in the novel, as an intervention of chaos into order or routine, is concordant with a certain genre convention. M. Bakhtin wrote that in novels from the $17^{\text {th }}$ - and $18^{\text {th }}$-century there exists the so-called "adventuristic time", and that contingency itself is represented by "the specific time during which irrational forces intervene in human life" (Bakhtin 2004, p. 94). At the same time in this type of work the contingent was clearly subordinated to plot teleology: "Should something happen a minute earlier or a minute later, that is, should there be no chance simultaneity or chance disjunctions in time, there would be no plot at all, and nothing to write a novel about" (Bakhtin 2004, p. 92).

The hero-narrator underlines his own consciousness of this genre convention: "I have been the continual sport of what the world calls Fortune (...) the ungracious Duchess has pelted me with a set of as pitiful misadventures and cross accidents as ever small HERO sustained" (Sterne 2003, p. 10-11). The narrator's ironic attitude throughout the whole work serves as proof of distance from this convention. This irony is manifested mostly by contradiction between the self-referential announcements that mostly concern the novel's plot and what partially stem from the above-mentioned consistent non-implementation of these projects by the narrator. At the beginning of the work one may find such words as: "For which cause, right glad I am, that I have begun the history of myself in the way I have done; and that I am able to go on, tracing everything in it, as Horace says, ab Ovo" (Sterne 2003, p. 8). The fact that the narrator assumes some kind of order of his story, despite it being in a state of disintegration, is 
confirmed several hundreds of pages later: "No - I think, I said, I would write two volumes every year, provided the vile cough which then tormented me, and which to this hour I dread worse than the devil, would but give me leave - and in another place - (but where, I can't recollect now) speaking of my book as a machine (...) I swore it should be kept a going and rate these forty years" (Sterne 2003, p. 431). One may be sure, however, that none of the more specific plans of the narrator-hero came to realization. Tristram Shandy is an example of an open work, which ends without a particular motivation and does not fulfill the Aristotelian requirement from Poetics of completeness of a literary work.

It is not only the fact that the narrator's declarations are not fulfilled in Tristram Shandy, but that they are also contradictory, or at least hard to reconcile. Already on the first pages of the novel one may experience the "antidoctrinal” attitude of the author: ,in writing what I have set about, I shall confine myself neither to his rules, nor to any man's rules that ever lived” (Sterne 2003, p. 8). Or: „All I contend for, is the utter impossibility for some volumes, that you, or the most penetrating spirit upon earth, should know how this matter really stands" (Sterne 2003, p. 46).

It is worth underlining that these are only examples of vast numbers of similar places in Sterne's novel. There are many levels embedded in the work, which put each other in question, rather than create a coherent structure.

This self-referential element dominates the "story" in the novel by announcing (post) modern "crises" of the plot (similar mechanisms are well-described in literary theory, we may refer here e.g. to the difference between histoire and discours or to various problems connected with mimesis). This omnipresent self-referentialism engages the reader in a reflection over the work itself, and does not allow him to focus on the plot, intrigue.

The question about the causes of such a discrepancy may be answered - and this answer will be useful especially for those who are troubled by these "inconsequences" - by stating that the narrator-hero is just an ironist and so the reader should also adopt such an ironic attitude. If one will not believe Tristram, one will be faithful to him; this is an uneasy formula of cooperation between the reader and narrator.

The above-mentioned problem is simultaneously connected to the way that Tristram presents himself in the novel. And so we encounter here the issue that absorbs researchers of first-person narratives (Kaniewska 1997, p. 203-216) - the problem of the narrator who is also the character in a literary work.

The uniqueness of Tristram Shandy in this type of prose is based on the fact that Tristram-as-hero is present in the novel in a very limited way. His life is supposed to be the 
main subject of the work, but it does not happen, because Tristram first cannot be born and then he actually disappears from the plot. This is another argument supporting the thesis about the ironic attitude of the narrator towards genre conventions. We may only believe that Tristram was "the continual sport of what the world calls Fortune" (Sterne 2003, p. 10), for not much is known about his numerous experiences. In this sense, Tristram does not develop as a hero, despite the fact that the novel is supposed to be a representation of not only his thoughts, but also his life . He stays, as the researcher writes, "eternally young" (Kaniewska 2000, p. 31-40).

Instead of a history concerning the life of the hero-narrator, one reads a work in which the very act of narration is emphasized. At the same time, it is the digressions of the narration itself that so effectively shatter its unity. This is mentioned by Tristram: "It is so long since the reader of this rhapsodical work has been parted from the midwife, that it is high time to mention her again to him, merely to put him in mind that there is such a body still in the world, and whom, upon the best judgment I can form upon my own plan at present, - I am going to introduce to him for good and all” (Sterne 2003, p. 33).

In another place the narrator reveals a general principle of his story: „The machinery of my work is of a species by itself; two contrary motions are introduced into it, and reconciled, which were thought to be at variance with each other. In a word, my work is digressive, and it is progressive too, - and at the same time" (Sterne 2003, p. 63-64). Of course, this is a perverse reflection because it is digressiveness that dominates over progressiveness in the novel, unless - and this may be Tristram-as-ironist's point - the sign of progressiveness is just the growing size of the work.

Tristram Shandy should be considered as a nonplot-based work, which is characterized, among other things, by disintegration of the hero's character (Owczarek 1999, p. 12). Moreover, such literary pieces functionalize the Aristotelian principles of continuity and coherency by limiting them to smaller thematic or event entities, while on the other hand they abandon the principle of completeness, which is: "a resolution of event order: namely hero's movement from happiness to unhappiness or the other way round" (Owczarek 1999, p. 15-19).

It is in the above-mentioned model of narration that the second way that contingency functions in Tristram Shandy is present. Here, one needs to remember the contractual nature of this division. The narrative contingency in Sterne's novel was mentioned already by M. Kundera: "Against the reduction of the world to the casual succession of events, Sterne's 
novel, by its very form, affirms that poetry lies not in action, but there where action stops; there where the bridge between a cause and an effect has collapsed and thought wanders off in sweet lazy liberty. The poetry of existence, says Sterne's novel, is in digression. It is in the incalculable. It is on the other side of causality. It is sine ratione, without reason. It is on the other side of Leibniz's statement" (Kundera 1986, p. 161-162). Tristram's narration itself holds contingency in it, which is seen by Kundera in "the cease of action", that is, in permitting the full potentiality of events in the story.

Other researchers also mention this meaning of contingency. M. Sokołowski writes about association techniques, which are used by Tristram-the-narrator. They are enrooted in a wider phenomenon, in the so-called associative thinking: "[This thinking] is [first of all] multidimensional and rich. Ideas may link each other in an unseen and unexpected way. All sets of thoughts are potentially possible, but not all of them have found their use in art yet. Secondly, it is unlimited and open. Each thought may be accompanied by another, as an association. The idea is the beginning of a chain of thoughts or an origin of a new idea" (Sokołowski 2007, p. 66).

Of course, these recognitions are similar to earlier reflections that place Tristram among works of open composition (e.g., digressional)., but they simultaneously emphasize the contingency in the narration itself. Tristram, while describing his own dilemmas of being a "storyteller", uses the metaphor of the road: "O ye POWERS! (for powers ye are, and great ones too) - which enable mortal man to tell a story worth the hearing (...) Ye, who preside over this vast empire of biographical freebooters (...) will you do one thing? I beg and beseech you (...) that where-ever, in any part of your dominions it so falls out, that three several roads meet at one point, as they have done just here, - that at least you set up a guide-post, in the center of them, in mere charity to direct an uncertain devil, which of the three he is to take" (Sterne 2003, p. 187). This is how this contingency reveals itself in L. Sterne's novel. On the one hand, it influences the life of Tristram-the-narrator, and on the other hand, his method of narration.

The categories proposed here allow the experiences of Tristram to be included in some contexts, but they support - to use Jacques Derrida's term - the "undecidability", which is based on the fact that one cannot separate Tristram's existence from his narration. Telling about one's life is already done in a contingent way, so the experiences of Tristram-the-hero, on the one hand, are compensated in narration, but on the other, they remain an existential burden (this refers mainly to the birth of the hero-narrator). The event of Tristram's birth is 
not only an intellectual reflection on one's life, but also constitutes an overtaking of some of the father's beliefs, which is later confirmed at the end of the novel in "Walter Shandy's diatribe against procreation" (Carnochan 1977, p. 120). It also makes one think of contingency in the opposite way, that is, not about the adult, Tristram, who understood the role of chance in human's life and wrote his own story, but about Tristram, a man "not taken care of", who is stuck in adolescence, "metaphorizing" his own "misfortune" through specific narration and half-ironic interpretation of his own birth. This is one of the features present in first-person narration novels, which show human life as intermingling layers of autointerpretative acts.

So Tristram's life and narration are continually mutually illuminating each other, which disturbs the reader. For example, one does not know whether the circumstances of Tristram's birth affected his mode of storytelling, or his later experiences formed the way he interprets this event and narrates it. The reader simply cannot decide here - he is constantly torn between these possibilities. In my view this paradox is the main feature of Sterne's work.

Tristram's birth is a work of chance that is fully applicable to Bakhtin's categories. And even though the first pages of the novel prove that the narrator has an ironic attitude towards the genre convention which refers to such concept of contingency, this interpretation of his own birth sounds authentic, despite being taken from Walter. It is relevant in view of the "plot immaturity" of the main character, who sentences himself to "eternal youth" by using the illusions characteristic for this stage of life. These illusions keep him somehow beside the world that does not want him and in which he appeared by accident. This event is explained, by Jung's psychology: „The consciousness of a little child is settled in a multi-dimensional time of unconsciousness and in the beginning the child does not have the knowledge about linear, physical time. This is why it cannot understand the inevitability of physical death (...). Adults preserve a more or less clear sense of eternity in their unconsciousness, which is accompanied by illusion of one's immortality (...). Psychological attitude of a given person may be very much marked by self-confidence of being someone, whose life does not have clear borders. This way the need of experiencing one's exceptionality is fulfilled" (Dudek 2002, p. 208). Tristram's interpretation of his own birth is important for his relation with father as well. At the end of the novel Walter gives his so-called diatribe against procreation: „Every evil and disorder in the world of what kind or nature soever (...) was owing one way or other to the same unruly appetite [sexual - T.U.] (...). A passion (...) bends down the faculties, and turns all the wisdom, contemplations and operations of the soul backwards (...) equals wise men with fools, and makes us come out of our caverns and hiding-places more like satyrs and four-footed beasts 
than men (...). For what reason is it, that all the parts thereof (...) are so held as to be conveyed to a cleanly mind by no language, translation, or periphrasis whatever? - The act of killing and destroying a man (...) is glorious - and the weapons by which we do it are honourable" (Sterne 2003, p. 586-587).

W. B. Carnochan commented on Walter's words: „The fact that he [Walter] is telling the plain truth does not make it easier to listen to him; by willing Tristram not to be born, he submits him to the fate he has fled from and (perhaps) thinks himself to have escaped)" (Carnochan 1977, p. 127). So the narrator, by referring to his father's words, becomes a person who „nourishes destruction in himself” (Carnochan 1977, p. 127). In these excellent remarks, one can see that the researcher therefore emphasizes the regularity in which the father's views are illustrated by the son's life (or its lack in the novel).

Narrative contingency, which reveals itself in self-referentialism, digressiveness, and the plot-less character of the work, is anti-teleological. Among other things, it is the literary feature of completeness that was to guarantee, according to Aristotle's Poetics, the receiver of the art a specific form of fulfillment. In Sterne's novel there is no such possibility: "Sequences of events connected with each other are in non-plot prose begin and end in an unmarked, contingent, unjustified place. In plot-based prose the course of events is determined thematically, it unfolds from the »tying « to the »untying « and finishes with inversion if the main character's initial situation" (Owczarek 1999, p. 28). The fact that Tristram Shandy exceeds the aesthetic principles formulated in Stagiritan's work is, in some way, obvious. The more interesting fact is that the way of leading narration - contingent - is a way of escaping one's death. If the hero-narrator aimed at writing the story of his own life, then his existence must deplete itself during the novel's development (with the growing hero). This aim itself is associated by Tristram with death, for instance, when he speaks about a straight line as follows: „In this last volume I have done better still - for from the end of Le Fever's episode, to the beginning of my uncle Toby's campaigns, - I have scarce stepped a yard out of my way. If I mend at this rate, it is not impossible (...) I may arrive hereafter at the excellency of going (...) [in] a line (...) as straight as I could draw it (...) turning neither to the right hand or to the left. This right line, the path-way for Christians to walk in! sat divines - The emblem of moral rectitude! says Cicero - The best line! say cabbage-planters - is the shortest line, says Archimedes, which can be drawn from one given point to another (...). Pray can you tell me, that is, without anger, before I write my chapter upon straight lines - by what mistake - who told them so - or how it has come to pass, that your men of wit and genius have all along confounded this line, with the line of GRAVITATION?" (Sterne 2003, p. 426-427). This 
ironic association of a straight line with gravity is connected with human mortality, because the force of gravity is what unconditionally "brings us, most seriously, back to earth" (Carnochan 1977, p. 125). In another place the narrator will speak against associating perfectness with stillness or slowness: „Now, I (...) think differently; and that so much of motion, is so much of life, and so much of joy - and that to stand still, or get on but slowly, is death and the devil" (Sterne 2003, p. 444). Here again is the paradox of the novel revealed. On the one hand Tristram-as-narrator moves in various directions and tries to oppose this "straight line", or the "line of gravity", but on the other hand, as a hero he inertly falls under the influence of time. The attempt to defeat time with one's activity, taken in the seventh volume, will end in a failure. Tristram Shandy is sometimes a funny work, however in this moment and in many others lies a painful and bitter irony. In Tristram's rejection of motion hides a sort of auto-interpretation. As W.B. Carnochan observes, until the seventh book Tristram himself is in a sort of stillness, so that by criticizing this state "he implicates himself (...) It is as if he were admitting to joylessness" (Carnochan 1977, p. 124).

Tristram refers to his birth in an unequivocal way. This coincidence is theoretically "typically Bakhtinesque", however in the light of the whole work the case of contingency itself becomes more complicated. Contingency of birth becomes partially a result of autointerpretation of the hero-narrator and partially it may influence, as an experience, the selfunderstanding of Tristram. In this aspect it is impossible to divide the life and the story or to prioritize either the hero-narrator's experience or intellectual reflection. Such a complication, or rather, the unsolvable character of the problem is characteristic of some types of firstperson narrations. Referring to R. Koschany's terminology one may say that in L. Sterne's novel contingency is made existential. R. Koschany describes the phenomenon thus: "I would like to first of all emphasize the understanding of contingency as an artistic category (an event as a plot unit, a change of relations between the characters, noticeable only on the level of text) and contingency as an existential category (an event as a change of relation in one biography, referring to the narrator's past and to his interpretational way inside). This specific transformation is recognized in a hermeneutic research perspective, or better - in a hermeneutic attitude. This way is suggested by P. Ricoeur: from the text to existence (and the other way round) (...). What is visible here, are two zones whose inseparability I tried to underline - existence and poetics. Poetics, which includes what is originally existential and which gives meaning to particular events. According to the principal of scheme analogy, it agrees with the distinction into plot understood as an objective, chronological, causal 
arrangement of events and narration, which places these events in such a way, so as to organize them - using P. Ricoeur's words - in a sense" (Koschany 2006, p. 245-246).

This, in turn, leads to a certain historic-literary reflection. On the grounds of this "philosophy of chance" it is revealed that Tristram Shandy constitutes one of the first and most important links in the development of the trend opposite to "classic novels". It is common to look for a certain novel paradigm among the authors of the $19^{\text {th }}$-century (e.g. H. Balzac, E. Zola, G. Flaubert) and to locate the distinctly different implementations of the genre later in time. But even these later dissents from the classical paradigm are sometimes negatively marked, and in fact, since the end of the 19th-century, numerous opinions about the crisis of the novel have appeared (Bartoszyński 2004, p. 9-26).

Against the background of the above reflections on Tristram Shandy one may recall a set of characteristics that were to be put in contrast to the traditional genre model by the later, modern and postmodern novel: "The reduction of plot, destruction and relativization of characters, resignation from the cause and effect or chronological order of events, putting the narrative medium in the place of a suspect (...) exposing the fictional character of the presented world and its ontological incoherency, depriving the text of the subject and later of the author, at last the resignation from the classically mimetic way of existence of a novel" (Kaniewska 2000, p. 17). And here are possible reactions on coming into contact with such a work, especially in as regards the so-called plot crisis: "Some of these techniques, especially operating with the alternativeness, multi-version character of the solutions, create essentially a feeling of disorientation. The reader of an innovative novel of this type is sometimes endangered by a sense of non-participating in a zone of a narrative genre. He is moved into the atmosphere of a reportage, journal or an essay. If setting plots is considered a derivative of a narrative skill of presenting a human as a being, whose identity is built on a consciousness of transformation in time, then the narrative expression of this structure is a condition of showing a man in a way of existence specific for him” (Bartoszyński 2004, p. 122).

One may notice a certain kinship between the novelistic models reconstructed by the cited researchers and Tristram Shandy. It is especially worth noting the words of $\mathrm{K}$. Bartoszyński, who refers to the anthropological aspect of narration. In this context Tristram Shandy reveals its interesting side. The narrator of the novel announces that he will write the history of his life, but he does not do it. Thereby he does not fulfill a certain expectation of the receiver, which is based on the will to understand human fate as an entity subordinate to a superior goal. A compensative function in this understanding is opposed by Sterne's novel in a radical way. It sentences the hero-narrator to "eternal youth", and by so doing keeps the 
reader himself in a state of expectation for fulfilling the announced story. This radical approach is connected with contingency. The fact that the narrator may move in such a free way stems from his refusal to assume any superior target of his story (e.g., he cannot separate the "really important part" from "an anecdote"). One of the consequences of this "antiessentialism", or the necessity of writing everything down in the face of not being able to identify what is important, is shown by the hero-narrator himself: "I am this month one whole year older than I was this time twelve-month; and having got, as you perceive, almost into the middle of my fourth volume - and no farther than to my first day's life - 'tis demonstrative that I have three hundred and sixty-four days more life to write just now, than when I first set out; so that instead of advancing, as a common writer, in my work with what I have been doing at it - on the contrary, I am just thrown so many volumes back - was every day of my life to be as busy a day as this - And why not? - and the transactions and opinions of it to take up as much description - And for what reason should they be cut short? as at this rate I should just live 364 times faster than I should write - It must follow, an' please your worships, that the more I write, the more I shall have to write - and consequently, the more your worships read, the more your worships will have to read" (Sterne 2003, p. 257).

B. Kaniewska and others pointed out that M. Kundera played a large role in the rehabilitation of Sterne's novel (or the $18^{\text {th }}$-century novel as a whole) is: „I often hear it said that the novel has exhausted all its possibilities. I have the opposite impression: during its 400-year history, the novel has missed many of its possibilities; it has left many great opportunities unexplored, many paths forgotten, calls unheard. Tristram Shandy is one of those great lost opportunities" (Kundera 1985).

Much attention is focused on these issues to authenticate the proposition of applying the above-mentioned category of "existential contingency" in deliberation over Sterne's novel. Referring to different opinions of the researchers, R. Koschany puts forth the following thesis: „Basically since the old Greek romance until the end of 18th century novel has been considered a set of chances" (Koschany 2006, p. 231). One needs to state that this contingency is the "artistic" one, which can be shortly referred to as "Bakhtinesque", that is, subject to a certain plot teleology. Taking into account the "convention of generalization" in which R. Koschany's opinion is being expressed and that is connected with the above, the relative uniqueness of Tristram Shandy among the novels of that time, a correction may be introduced in the distinction made by the above-mentioned researcher. And so one may already observe an existential case in Tristram Shandy, which is a novel from the 18th 
century. The previous remarks sufficiently prove the thesis of "filtering" the category of contingency through Tristram's existence. The words of the author of Przypadek himself may serve as an additional argument. He says that the transformation of contingency, its "existentialization", was helped by "self-referential tendencies" and "schemes of reflective narration about one's past, which may be realized in each first-person narration" (Koschany 2006, p. 232-234). These two features are, obviously, present in the novel.

Another important and interesting aspect of Tristram's contingency may be observed within the frame of thought of the German philosopher O. Marquard. In In Defense of the Accidental he sees a chance for a man to accept his own contingency. The philosopher finds and rejects "the program of making man absolute" in the European thought. This process is noticeable, for example, in the idea of human "participation" in God or in trust in man's ability to make absolutely free choices: "Part of the program of making man absolute is an attempt to abrogate the human reality that opposes it: in the Greek tradition, to declare that reality not genuine; or, in the Christian tradition, to declare that reality temporary, already judged, and subject to eschatological recall; or - in the program's modern, pronounced form to bracket that reality out, precautionally and methodically" (Marquard 1991, p. 113). To clarify, this third "tradition of contingency" is the Cartesian philosophy of "methodical doubt:" that which is not absolutely sure must cautiously be rejected as false. Of course, the opposition to all forms of "making man absolute" is the acceptance of one's own contingency.

The path to allowing contingency leads, according to Marquard, through theodicy. Leibniz's idea of theodicy allowed the existence of evil in the world, as a condition for existence of the ultimate good. Around 1750 a crisis of this concept took place. In the face of this crisis there is a need for a "better" defence of God, which is proposed by the philosophy of history. A man creates history and thereby he is also accused of evil which exists in the world. And so, a man defends himself from this "overtribunalization" because of "an enormous need for unburdening" (Marquard 1989, p. 49) and through, as O. Marquard claims, the "process by which evils are rendered no longer evil" (Marquard 1991, p. 57). One of the types of evil that is made positive is metaphysical evil: ,Metaphysical evil also, and in particular, is rendered no longer evil. Finitude, in modern times, exhibits an irresistible rise and becomes (...) a positive ontological value, at the cost especially of what had hitherto been accepted as the preeminent ontological condition: that of immutability. Thus we arrive at the positive revaluation of mutability. The concept of mutability that is no longer a metaphysical defect comes into existence (...) as the concept of »history«" (Marquard 1991, p. 20). One has 
to remember that the acceptance of this mutability means accepting a concept of an accident which is not the subject to a superior goal or Necessity.

It is worth adding a few words of commentary to O. Marquard's conception. The philosopher says that until the second half of the $18^{\text {th }}$-century, contingency was judged negatively in European thought. It was considered to be something specifically belonging to man, who is a mortal and imperfect being. What was valued positively was the Necessity as an attribute of the Absolute. This was one of the more important levels in which an answer to the question, "If God exists, why is there evil?" was sought. According to the rejection of the "program of making man absolute" O. Marquard postulates to accept the fact that a human's life is a work of accident. He says that one should not await a certain higher necessity in which one could put one's life. And thinking about our lives in the context of this Necessity may bring more damage than acceptance of the fact that nothing in the world has a metaphysical justification.

The most interesting thing about the Marquardesque reflection over contingency is the concept of two formulas of contingency: "Either, that is, the accidental is »that which could also be different« and which we can change (...) This kind of accidental thing (...) is an arbitrary choosable or rejectable object of discretion, which I would like to call the »arbitrary accidental«, or the arbitrary. Or, on the other hand, the accidental is »that which could also be different « and is precisely not changeable by us (blows of fate, by which I mean illnesses, being born, and the like) I would like to call it the »fatefully accidental«, or the fateful" (Marquard 1991, p. 119).

These two versions of contingency may be found in Sterne's novel. On one hand, for Tristram, his birth was something "fatefully accidental". On the other hand, the method of narration in Tristram is accidental, but for another reason. It is characterized by liberty, no limitations (in form of a final goal), and digressiveness. So the way in which Tristram tells his story could be named, following the words of the German philosopher, "arbitrary accidental".

It is not accidental that one may notice that the second formula may be associated with freedom . This is a certain continuation of an idea enrooted in a "theodicy" tradition. This idea stated that "freedom is inevitably connected with evil (...) the fact of being free is logically inconsistent with inability of making evil" (Kołakowski 1988, p. 28). And what is "fatefully accidental" implicates some limits on life, something that is independent from us and not reducible - that is, it is not explained by any Necessity. After all: „[Human beings] do not choose their life absolutely, and this is because they have to die. To use Heidegger's words, they are »toward death«. A limit is fixed to their lives: »vita brevis«" (Marquard 1991, p. 
113). Therefore, modern contingency in Marquard's understanding would be a paradoxical category.

Tristram's "undecidability" appears to be the hero-narrator's recognition of the contingency of his own existence. On the one hand, this is why he pays so much attention to his birth and complains about the fate of an unwanted man. Here is the place to look for the reason for the non-plot character of the novel as a symptom of his fear of death, because for Tristram, the act of designating a distinct goal for the novel was in fact "deadly dangerous". On the other hand, the discovery of this contingency lets the hero-narrator speak freely, in which there is joy and "illusion of immortality". This illusion is achieved by Tristram's sentencing of himself, as a hero, to "eternal youth", which thereby allows him to look at the world with constant surprise, irony, and humour, and, above all, in a way not limited by some obligations.

And again it is necessary to accept Tristram's paradox or "undecidability". The burden of a non-culpable fate and approaching death remains in the novel. However, it was presented by Tristram-the-narrator - a man who discovered the saving, compensatory function of storytelling. But, again, it is also the opposite - the story only "out-talks" the existential experience.The Novel's "free" character eliminates Tristram-the-hero from "real life". Tristram was conceived by accident and he is afraid that his life is only a mistake. He is paralyzed by this thought - for him growing up is not a chance, but a direct way to death. Because of it Tristram does not want to tell the story of his life - he would like to disappear from the plot. In this context, Tristram's life -- full of humour and seriousness, joy and painappears to be a paradoxical and a modern example of the experience of contingency.

\section{Bibliography:}

Bakhtin M.M. (2004), Forms of Time and of the Chronotope in the Novel, [in:] Bakhtin M.M. (ed.), The Dialogic Imagination. Four essays, University of Texas Press, Austin.

Bartoszyński K. (2004), Kryzys czy trwanie powieści. Studia literaturoznawcze, Universitas, Kraków.

Carnochan W.B. (1977), Confinement and Flight. An Essay on English Literature of the Eighteenth Century, University of California Press, Berkeley.

Dudek Z.W. (2002), Podstawy psychologii Junga. Od psychologii głębi do psychologii integralnej, Eneteia, Warszawa. 
Holquist M. (ed.) (2004), The Dialogic Imagination. Four essays, University of Texas Press, Austin.

Kaniewska B. (1997), Świat w granicach ,ja”. O narracji pierwszoosobowej, Rebis, Poznań.

Kaniewska B. (2000), Śladami Tristrama Shandy, Poznańskie Studia Polonistyczne. Seria Literacka, Poznań.

Kołakowski L. (1988), Jeśli Boga nie ma... O Bogu, Diable, Grzechu i innych zmartwieniach tak zwanej filozofii religii, Znak, Kraków.

Koschany R. (2006), Przypadek. Kategoria egzystencjalna i artystyczna w literaturze i filmie, Wydawnictwo Uniwersytetu Wrocławskiego, Wrocław.

Kundera M. (1986), The Art of the Novel, Faber and Faber, London and Boston.

Marquard O. (1989), Farewell to Matters of Principle. Philosophical Studies, Oxford University Press, New York.

Marquard O. (1991), In Defense of the Accidental. Philosophical Studies, Oxford University Press, New York.

Owczarek B. (1999), Poetyka powieści niefabularnej, Wydawnictwo Naukowe PWN, Warszawa.

Sokołowski M. (2007), Techniki asocjacyjne. Angielskojęzyczne „poematy o wzroście indywidualnego umystu” od XVIII do XX wieku, Wydawnictwo IBL PAN, Warszawa.

Sterne L. (2003), The Life and Opinions of Tristram Shandy, Gentleman, Penguin Books, London.

\section{Netography:}

Kundera M. (1985), An Introduction to a Variation, "New York Times", http://www.nytimes.com/books/98/05/17/specials/kundera-variation.html, retrieved: 27.12.2009. 